\title{
Peranan Kebimbangan Karier terhadap Intensi Pindah Jurusan Kuliah pada Mahasiswa
}

\author{
Rhiany Rizqi Fahima, Sari Zakiah Akmal \\ Universitas YARSI, Jl. Letjend Suprapto Kav. 13 Jakarta Pusat \\ e-mail: rhianyrizqifahima@gmail.com
}

\begin{abstract}
Changing academic major could have negative impact on the students, such as increased fees and time for college. The intention of changing academic major is related to the mistake in choosing majors due to student's career indecision. Career indecision is a situation where an individual is experiencing difficulties, having lack of confident in making decisions or cannot commit to college or career. This study aims to see the role of career indecision on the intention of changing academic major among college students. The method used in this study was associative research. Participants in this study consisted of 175 students between 18 to 26 years old who enrolled in Jakarta-Bogor-Depok-Tangerang-Bekasi, selected with accidental sampling. The result indicates that the career indecision plays a $4.7 \%$ share to the intention of changing academic major. Therefore, reducing student's career indecisions is an alternative solution to decrease the intention of changing academic major.
\end{abstract}

Keywords: career indecision, intention of academic major change, college students

\begin{abstract}
Abstrak
Pindah jurusan yang dilakukan oleh mahasiswa dapat memberikan dampak negatif seperti bertambahnya biaya dan waktu kuliah. Intensi mahasiswa untuk melakukan pindah jurusan kuliah berkaitan dengan kesalahan dalam memilih jurusan akibat kebimbangan karier yang dialami mahasiswa tersebut. Kebimbangan karier merupakan suatu keadaan dimana seorang individu mengalami kesulitan, tidak yakin dalam membuat keputusan ataupun tidak dapat berkomitmen dengan jurusan kuliah, karier ataupun pekerjaan yang akan dijalaninya. Penelitian ini bertujuan untuk melihat peranan kebimbangan karier terhadap intensi pindah jurusan kuliah pada mahasiswa. Penelitian ini merupakan penelitian asosiatif. Partisipan dalam penelitian ini adalah 175 mahasiswa berusia 18-26 tahun yang berkuliah di Jakarta-Bogor-Depok-TangerangBekasi, yang dipilih berdasarkan teknik accidental sampling. Hasil penelitian menunjukkan bahwa kebimbangan karier berperan sebesar $4.7 \%$ terhadap intensi pindah jurusan kuliah. Oleh karena itu, salah satu upaya untuk mengurangi intensi pindah jurusan pada mahasiswa adalah dengan mengatasi masalah kebimbangan karier yang dialami.
\end{abstract}

Kata kunci: kebimbangan karier, intensi pindah jurusan kuliah, mahasiswa

\section{Pendahuluan}

Karier dapat berubah karena adanya perubahan pada tahap perkembangan seseorang dan pengalaman yang dimiliki (Crown Financial Ministries, 2007). Pada masa perkuliahan, perubahan karier pada mahasiswa bisa terjadi dengan melakukan pindah jurusan kuliah, dimana disebut juga sebagai academic major change (Greenhaus \& Callanan, 2006). Penelitian yang dilakukan oleh Johnson (2005) terhadap 383 mahasiswa di Lewis-Clark State College menunjukkan bahwa $40 \%$ dari mahasiswa tersebut pernah melakukan pindah jurusan kuliah. Selain itu, berbagai data juga menunjukkan masih banyaknya mahasiswa yang melakukan pindah jurusan kuliah (Anschuetz, 2015; Nugroho, 2016; Ramos, 2013). Pindah jurusan kuliah tidak hanya dilakukan oleh mahasiswa di semester awal, namun juga pada mahasiswa di semester lainnya. Survey yang dilakukan oleh peneliti di salah satu universitas swasta di Jakarta menunjukkan bahwa dari 38 mahasiswa yang menginginkan untuk pindah jurusan, $42 \%$ diantaranya adalah mahasiswa tahun pertama, dan 58\%-nya 
adalah mahasiswa di atas tahun kedua kuliah.

Keputusan mahasiswa untuk pindah jurusan kuliah dapat berdampak positif ataupun negatif. Hasil penelitian yang dilakukan oleh Anderson (dalam Peterson, 2006) menunjukkan bahwa pindah jurusan kuliah yang dilakukan mahasiswa lebih banyak memberikan dampak positif dan tidak akan banyak menunda waktu kelulusan dari mahasiswa. Menurut Greenhaus dan Callanan (2006), mahasiswa yang melakukan pindah jurusan kuliah akan merasa lebih puas dengan jurusan kuliahnya yang baru. Namun, hasil penelitian yang dilakukan oleh Foraker (2012), menunjukkan bahwa dampak positif tersebut hanya terjadi pada mahasiswa yang melakukan pindah jurusan di tahun pertama kuliah. Sementara itu, pada mahasiswa yang melakukan pindah jurusan kuliah setelah tahun pertama akan memberi beberapa dampak negatif seperti biaya kuliah yang tidak efisien dan memperlambat waktu kelulusan (Anschuetz, 2015; Jones \& Jones, 2012; Sklar, 2014). Adanya perbedaan pendapat mengenai dampak dari pindah jurusan kuliah, membuat perlu diadakannya penelitian terhadap kecenderungan mahasiswa untuk melakukan pindah jurusan kuliah.

Menurut Ajzen (2012), faktor penentu langsung dari suatu perilaku adalah intensi untuk melakukan perilaku tersebut. Oleh karena itu, untuk mengukur pindah jurusan yang dilakukan oleh mahasiswa difokuskan pada intensi atau niat bukan perilakunya. Secara teoretis belum ada penjelasan yang baku mengenai definisi dari intensi pindah jurusan kuliah. Namun, berdasarkan theory of planned behavior milik Ajzen (2012) dalam menentukan intensi suatu perilaku harus didefinisikan secara jelas berdasarkan prinsip TACT (target, action, context, dan time). Pada penelitian ini, targetnya adalah mahasiswa, dengan perilaku yang akan dilihat intensinya adalah pindah jurusan. Kemudian, pindah jurusan yang dilakukan adalah dalam konteks jurusan kuliah, dengan waktu pindahnya adalah saat tahun akademik berikutnya. Oleh karena itu, berdasarkan prinsip TACT maka dapat disimpulkan bahwa pengertian dari intensi pindah jurusan kuliah adalah kecenderungan mahasiswa untuk melakukan pindah jurusan kuliah pada tahun akademik berikutnya.

Terdapat beberapa faktor yang berperan dalam keputusan mahasiswa untuk melakukan pindah jurusan kuliah, seperti keterlibatan sosial, status sosialekonomi (Taylor, 2013), kesempatan kerja pada jurusan tertentu (Peterson, 2006), dukungan dari keluarga dan teman sebaya (Welcome, 2014), keahlian, self-efficacy career, pengalaman masa lalu dan kesalahan individu dalam membuat pilihan karier (Greenhaus \& Callanan, 2006). Salah satu faktor yang berperan penting dalam keputusan mahasiswa untuk melakukan pindah jurusan kuliah adalah adanya kesalahan dalam pengambilan keputusan terkait karier (jurusan kuliah).

Penelitian menunjukkan bahwa kesalahan dalam pengambilan keputusan terkait karier dapat membuat seseorang melakukan perubahan karier yang cukup besar (Mahoney, Katona, McParland, Noble, \& Livingston, 2004; Peterson, 2006). Kesalahan mahasiswa dalam menentukan jurusan kuliah yang mereka ambil, merupakan salah satu tanda adanya kebimbangan dalam pemilihan karier, dimana dalam konstruk psikologi dikenal sebagai career indecision (Greenhaus \& Callanan, 2006; Pečjak \& Košir, 2007; Guay, 2006). Kebimbangan karier merupakan suatu keadaan dimana seseorang tidak bisa membuat pilihan terkait karier yang mereka inginkan (Guay, 2006). Menurut Osipow (dalam Daniels, Stewart, Stupnisky, Perry, \& LoVerso (2011) kebimbangan karier merupakan suatu tahap perkembangan normal yang terjadi pada setiap individu selama proses memilih karier yang potensial dan merasakan kesulitan dalam memilih suatu karier yang akan dijalaninya. 
Banyak peneliti mendeskripsikan seorang individu menjadi bimbang ketika individu tersebut belum memilih suatu jurusan kuliah, ketika mereka kurang yakin dengan jurusan yang dipilihnya serta ketika mereka tidak bisa menentukan tujuan kariernya (Greenhaus \& Callanan, 2006). Penelitian yang dilakukan oleh Gordon dan Steele (2003) yang dilakukan selama kurun waktu 25 tahun terhadap 19.813 mahasiswa baru di Universitas Ohio, menunjukkan bahwa sebanyak $86 \%$ mahasiswa masih tidak yakin dengan jurusan kuliah yang telah mereka pilih. Selain itu, survey awal yang peneliti lakukan terhadap 116 mahasiswa di universitas swasta di Jakarta menunjukkan sebanyak 20 mahasiswa tidak yakin dengan jurusan yang dipilihnya.

Menurut Greenhaus dan Callanan (2006), kebimbangan karier yang dialami oleh mahasiswa merupakan hal yang wajar, dan merupakan suatu proses perkembangan karier yang terjadi pada masa perkuliahan. Namun, ketika kebimbangan karier yang dialami oleh mahasiswa tidak segera ditangani maka akan berdampak pada permasalahan psikologis dan rendahnya pencapaian akademik dari mahasiswa tersebut (Greenhaus \& Callanan, 2006; Intani \& Surjaningrum, 2010). Selain itu mahasiswa yang tidak berkuliah di jurusan yang sesuai dengan keinginannya akan tidak bersemangat dalam menjalani perkuliahannya (Greenhaus \& Callanan, 2006), bahkan memiliki kemungkinan yang lebih besar untuk drop-out (Kim \& Kim, 2017). Oleh karena itu, mahasiswa yang mengalami kebimbangan karier akan cenderung menginginkan pindah jurusan kuliah (Peterson, 2006). Jika mahasiswa tersebut melakukan pindah jurusan kuliah, mereka akan dapat memilih jurusan yang sesuai dengan keinginannya (Greenhaus \& Callanan, 2006). Sehingga peneliti berasumsi bahwa terdapat peranan kebimbangan karier dalam memprediksi intensi mahasiswa untuk melakukan pindah jurusan kuliah. Penelitian ini menjadi penting dilakukan karena selama ini belum ada penelitian terkait di Indonesia yang melihat peranan kebimbangan karier terhadap intensi mahasiswa untuk pindah jurusan kuliah.

Penelitian ini dilakukan untuk melihat peranan kebimbangan karier terhadap intensi pindah jurusan kuliah pada mahasiswa. Dengan adanya penelitian ini, diharapkan dapat menjadi sumbangan pemikiran untuk melakukan kajian serta diskusi mengenai tema peran kebimbangan karier terhadap intensi pindah jurusan kuliah pada mahasiswa.

\section{Metode Penelitian}

Penelitian ini melibatkan dua variabel yaitu intensi pindah jurusan kuliah sebagai variabel kriteria (variabel terikat) dan kebimbangan karier sebagai variabel prediktor (variabel bebas).

\section{Subjek Penelitian}

Subjek dalam penelitian ini berjumlah 175 orang mahasiswa aktif yang berkuliah di Jakarta-Bogor-Depok-Tangerang-Bekasi (JABODETABEK) berusia 18-26 tahun, dengan rata-rata usia 20 tahun $(\mathrm{sd}=1.531)$.

\section{Instrumen Penelitian}

Instrumen dalam penelitian ini berupa kuesioner yang terdiri dari tiga bagian, yaitu:

1. Data demografi, terdiri dari usia, jenis kelamin, asal universitas, asal jurusan, semester kuliah, IPK, urutan pilihan jurusan kuliah dan pihak yang menentukkan pilihan jurusan kuliah.

2. Skala Career Decision Scale.

3. Skala intensi pindah jurusan kuliah.

\section{Metode Analisis Statistik}

Uji normalitas. Uji normalitas data dalam penelitian ini dilakukan dengan menggunakan metode KolmogorovSmirnov. Menurut Dahlan (dalam Oktaviani \& Notobroto, 2014) Kolmogorov-Smirnov merupakan metode yang tepat digunakan untuk uji normalitas 
pada penelitian dengan sampel lebih dari 50 .

Uji hipotesis. Penelitian ini menggunakan uji regresi hirarki untuk menguji hipotesa. Uji regresi hirarki dilakukan untuk menentukan pengaruh variabel kebimbangan karier terhadap intensi pindah jurusan kuliah pada mahasiswa, dengan mempertimbangkan pengaruh variabel prediktor intensi lainnya (sikap, norma subjektif dan perceived behavior control). Untuk menentukan peranan variabel lain dalam memengaruhi intensi pindah jurusan, sebelum uji regresi, dilakukan analisa uji beda dan korelasi variabel-variabel yang secara teoretis terkait dengan intensi pindah jurusan.

\section{Hasil Penelitian dan Pembahasan}

\section{Deskripsi Subjek Penelitian}

Subjek dalam penelitian ini berjumlah 175 orang mahasiswa aktif yang berkuliah di JABODETABEK berusia 18-26 tahun, dengan rata-rata usia 20 tahun $(\mathrm{sd}=1.531)$. Dari 175 subjek, mayoritas berjenis kelamin perempuan $(66.3 \%)$, yang berasal dari berbagai macam universitas, namun, mayoritas subjek berasal dari universitas swasta (68\%). Selain itu, mayoritas subjek sudah berada di tahun ke-4 kuliah (34.2\%), memiliki IPK 2.76-3.50 (65.7\%). Pada kategori urutan pilihan jurusan kuliah, mayoritas subjek memilih jurusan yang saat ini dijalani sebagai pilihan pertama (54.3\%). Pada kategori pihak yang memilih jurusan kuliah mayoritas karena keinginannya sendiri $(75.4 \%)$. Mayoritas orang tua subjek memiliki kemampuan untuk membiayai keinginan subjek untuk pindah kuliah $(58.3 \%)$.

\section{Uji Normalitas Data Penelitian}

Uji normalitas dilakukan untuk melihat apakah data penelitian berdistribusi normal atau tidak. Pada penelitian ini uji normalitas dilakukan dengan menggunakan uji Kolomogorov-Smirnov. Data dikatakan berdistribusi normal jika nilai signifikansi yang didapatkan lebih dari $.05(p>.05)$ (Irianto, 2004).

Tabel 1

Uji Normalitas Data

\begin{tabular}{lcl}
\hline Variabel & $K-S Z$ & $P$ \\
\hline Kebimbangan karier & 0.755 & $.619 *$ \\
Intensi pindah jurusan & 3.545 & .000 \\
Attitude toward behavior & 1.612 & .011 \\
Subjective norms toward & 1.505 & .022 \\
behavior & & \\
Perceived behavior control & 0.826 & $.503^{*}$ \\
Residual & 0.932 & .351 \\
\hline *p $>.05$ & &
\end{tabular}

Berdasarkan hasil uji normalitas dapat dilihat bahwa pada variabel kebimbangan karier dan dimensi subjective norms pada variabel intensi berdistribusi normal, sedangkan variabel intensi pindah jurusan dan dimensi attitude, serta perceived behavior control data tidak berdistribusi normal. Selain itu, tabel 1 juga menunjukkan nilai residual berdistribusi normal, sehingga selanjutnya dapat diuji dengan menggunakan uji statistik regresi hierarki.

\section{Uji Beda Intensi Pindah Jurusan Kuliah Berdasarkan Data Demografi}

Uji beda pada penelitian ini dibagi menjadi dua. Pada variabel dengan dua kategori dilakukan melalui uji $U$ Mann Whitney, sedangkan pada variabel dengan lebih dari dua kategori uji beda dilakukan melalui uji Kruskal Wallis. Tabel 2 menunjukkan hasil uji beda data demografi terkait intensi pindah jurusan kuliah.

Tabel 2

Hasil Uji Beda

\begin{tabular}{lll}
\hline Data demografi & $\mathrm{U} / \mathrm{H}$ & $p$ \\
\hline Kemampuan & $\mathrm{U}=3665.5$ & .851 \\
Tahun kuliah & $\mathrm{H}=8.364$ & .079 \\
IPK & $\mathrm{H}=1.678$ & .622 \\
Urutan pilihan jurusan & $\mathrm{H}=7.910$ & $.048^{*}$ \\
Pihak yang menentukan & $\mathrm{H}=7.927$ & $.048^{*}$ \\
pilihan & & \\
$* p<.05$ & &
\end{tabular}

Berdasarkan tabel 2 dapat terlihat bahwa terdapat perbedaan intensi pindah 
jurusan kuliah pada variabel urutan pilihan jurusan kuliah $(\mathrm{H}=7.910 ; p=.048<.05)$ dan pihak yang menentukan pilihan jurusan $(\mathrm{H}=7.927 ; p=.048<.05)$. Akan tetapi, tidak terdapat perbedaan intensi pindah jurusan kuliah pada variabel IPK $(\mathrm{H}=$ $1.678 ; p=.622>.05)$, tahun kuliah $(\mathrm{H}=$ $8.364 ; p=.079>.05)$ dan kemampuan orang tua $(\mathrm{U}=3665.5 ; p=.851>.05)$.

\section{Korelasi antara Kebimbangan Karier dan Intensi Pindah Jurusan Kuliah pada Mahasiswa}

Pada penelitian ini untuk melihat hubungan antara variabel intensi pindah jurusan kuliah dengan variabel lain yang diasumsikan memiliki hubungan dengan intensi pindah jurusan kuliah, seperti variabel urutan pilihan jurusan kuliah, pihak yang menentukan pilihan jurusan kuliah, kebimbangan karier, dimensi sikap, norma subjektif dan perceived behavior control akan dilakukan dengan metode statistik non-parametrik. Hasil analisis data dapat dikatakan berhubungan signifikan jika nilai signifikansi lebih dari $.05(p<$ $.05)$.

Berdasarkan tabel 4 terlihat bahwa urutan pilihan jurusan, sikap, norma subjektif, perceived behavior control dan kebimbangan karier berhubungan dengan variabel intensi. Namun, pada variabel pihak yang memilihkan jurusan kuliah tidak berhubungan dengan variabel intensi. Variabel yang berhubungan dengan intensi selanjutnya akan dilakukan uji linier.

\section{Regresi Hirarki antara Kebimbangan Karier dan Intensi Pindah Jurusan Kuliah pada Mahasiswa}

Uji regresi hirarki dilakukan pada variabel-variabel yang berkorelasi dengan intensi. Variabel urutan pilihan jurusan kuliah akan dimasukkan pada model 1 karena berasal dari data demografi. Pada model 2 akan ditambahkan variabel sikap, norma subjektif dan perceived behavior control yang merupakan bagian dari dimensi intensi. Lalu pada model 3 ditambahkan variabel kebimbangan karier sebagai variabel prediktor pada penelitian ini. Hasil dari uji regresi hirarki dapat dilihat pada tabel 4 .

Berdasarkan tabel tersebut dapat terlihat bahwa pada model 1, variabel urutan pilihan jurusan kuliah memiliki peranan sebesar $2.3 \% \quad\left(\Delta \mathrm{R}^{2}=0.023\right.$; $\left.\mathrm{F}_{\Delta \mathrm{R}}{ }^{2}=4.026 ; \quad p<.05\right) \quad$ terhadap intensi mahasiswa untuk melakukan pindah jurusan kuliah. Hasil ini menunjukkan bahwa urutan pilihan jurusan kuliah memiliki peranan yang sangat kecil terhadap intensi mahasiswa untuk melakukan pindah jurusan kuliah.

Variabel-variabel prediktor pada model 2 memiliki peranan sebesar $35.2 \%$ terhadap intensi pindah jurusan kuliah pada mahasiswa, dengan peningkatan sebesar $34.4 \%$ dari model $1\left(\Delta \mathrm{R}^{2}=0.344 ; \mathrm{F}_{\Delta \mathrm{R}}{ }^{2}=30.789\right.$; $p<.01)$. Namun dari 4 prediktor pada model 2 , hanya variabel sikap $(\beta=.031 ; p<.01)$ dan perceived behavior control (PBC) $(\beta=.029$; $p<.01)$ yang signifikan dalam memprediksi intensi mahasiswa untuk pindah jurusan kuliah. Hal ini menunjukkan bahwa 35.2\% keinginan mahasiswa untuk pindah jurusan kuliah hanya dipengaruhi oleh variabel sikap dan variabel perceived behavior control.

Pada model 3 terdapat peningkatan peranan variabel prediktor terhadap intensi mahasiswa untuk melakukan pindah jurusan kuliah menjadi 39.6\%. Variabel yang signifikan dalam memprediksi intensi mahasiswa untuk pindah jurusan kuliah pada model 3 hanya variabel sikap $(\beta=.029$; $p<.01), \quad$ PBC $\quad(\beta=.029 ; \quad p<.01) \quad$ dan kebimbangan karier $(\beta=.048 ; \quad p<.01)$. Variabel kebimbangan karier menaikkan nilai prediksi pada model 3 sebesar $4.6 \%$ $\left(\Delta \mathrm{R}^{2}=0.046 ; \mathrm{F}_{\Delta \mathrm{R}}{ }^{2}=13,343 ; p<.01\right)$. Hal ini menunjukkan bahwa $35 \%$ intensi mahasiswa untuk pindah jurusan kuliah dipengaruhi oleh variabel sikap dan PBC serta 4.6\% lainnya dipengaruhi oleh variabel kebimbangan karier. Namun, variabel urutan pilihan jurusan kuliah dan norma subjektif tidak memberikan pengaruh yang 
Tabel 3

Hasil Uji Korelasi

\begin{tabular}{lccccccc}
\hline Variabel & 1 & 2 & 3 & 4 & 5 & 6 & 7 \\
\hline Intensi (1) & & & & & & & \\
Sikap (2) & $.507^{* *}$ & & & & & & \\
Norma subjektif (3) & $.211^{* *}$ & .146 & & & & & \\
PBC (4) & $.393^{* *}$ & $.243^{* *}$ & $.190^{*}$ & & & & \\
Kebimbangan karier (5) & $.306^{* *}$ & $.161^{*}$ & .133 & .069 & & & \\
Urutan pilihan jurusan (6) & $.187^{*}$ & .141 & .119 & -.009 & $.17 *$ & & \\
Pihak yang memilihkan jurusan (7) & .134 & .132 & .083 & .096 & $.212^{* *}$ & $.450^{* *}$ \\
\hline
\end{tabular}

$* * p<.01 ; * p<.05$

Tabel 4

Hasil Uji Regresi Hirarki

\begin{tabular}{|c|c|c|c|c|c|c|}
\hline Model & Variabel & Adjusted $\mathrm{R}^{2}$ & $\Delta \mathrm{R}^{2}$ & $\mathrm{~F}_{\Delta \mathrm{R}}^{2}$ & $\beta$ & Sig. \\
\hline 1 & Urutan pilihan jurusan & 0.017 & 0.023 & 4.026 & 0.246 & .046 \\
\hline \multirow[t]{5}{*}{2} & (Model 2) & 0.352 & 0.344 & 30.789 & & .000 \\
\hline & Urutan pilihan jurusan & & & & 0.167 & .100 \\
\hline & Sikap & & & & 0.031 & .000 \\
\hline & Norma subjektif & & & & 0.007 & .102 \\
\hline & PBC & & & & 0.029 & .000 \\
\hline \multirow[t]{6}{*}{3} & (Model 3) & 0.396 & 0.046 & 13.343 & & .000 \\
\hline & Urutan pilihan jurusan & & & & 0.162 & .098 \\
\hline & Sikap & & & & 0.029 & .000 \\
\hline & Norma subjektif & & & & 0.005 & .212 \\
\hline & PBC & & & & 0.029 & .000 \\
\hline & Kebimbangan karier & & & & 0.048 & .000 \\
\hline
\end{tabular}

signifikan terhadap intensi mahasiswa untuk pindah jurusan kuliah ketika bersama-sama menjadi prediktor intensi dengan variabel sikap, PBC dan kebimbangan karier.

\section{Pembahasan}

Hasil penelitian ini menunjukkan bahwa kebimbangan karier yang dialami oleh mahasiswa memiliki peranan sebesar 4.6\% terhadap intensi untuk melakukan pindah jurusan kuliah yang dimiliki oleh mahasiswa di Jakarta - Bogor - Depok -
Tangerang - Bekasi (JABODETABEK). Hal ini menunjukkan bahwa ketika seorang mahasiswa memiliki tingkat kebimbangan karier yang tinggi maka ia juga akan memiliki intensi untuk pindah jurusan kuliah yang tinggi pula. Hasil penelitian ini sejalan dengan penjelasan dari Salomone (dalam Coco, 2000) yang menyatakan bahwa seseorang yang mengalami kebimbangan karier memiliki kemungkinan yang lebih besar untuk pindah jurusan kuliah. Selain itu hasil penelitian ini juga sejalan dengan hasil penelitian yang dilakukan oleh 
Mahoney dkk. (2004) yang menunjukkan bahwa seseorang yang mengalami kebimbangan karier akan melakukan perubahan karier yang cukup besar, dimana pada mahasiswa perubahan karier tersebut dapat terjadi melalui pindah jurusan kuliah. Mahasiswa yang mengalami kebimbangan karier cenderung merasa jurusan yang sedang dijalaninya tidak sesuai dengan keinginannya. Oleh karena itu, mereka akan merasa tidak puas dengan jurusan yang sedang dijalaninya, dan menginginkan untuk pindah ke jurusan yang sesuai dengan keinginan mereka.

Intensi mahasiswa untuk pindah jurusan kuliah tidak hanya dipengaruhi oleh faktor kebimbangan karier yang dialaminya. Beberapa faktor lain tersebut adalah faktor urutan pilihan jurusan kuliah, sikap, norma subjektif dan perceived behavior control terhadap perilaku pindah jurusan kuliah yang memiliki pengaruh sebesar $35,2 \%$ terhadap intensi pindah jurusan kuliah. Hal ini sejalan dengan theory of planned behavior yang menyatakan bahwa sikap, norma subjektif dan perceived behavior control sebagai prediktor utama dari intensi seseorang untuk melakukan suatu perilaku (Ajzen, 1991; Ajzen, 2011; Francis, Eccles, Johnston, Walker, Grimshaw, Foy, \& Bonetti, 2004). Faktorfaktor tersebut berperan besar dalam intensi yang dimiliki seseorang karena untuk melakukan pindah jurusan kuliah bukan hal yang mudah.

Hasil dari uji beda pada data demografi terkait intensi pindah jurusan kuliah menunjukkan terdapat perbedaan intensi pindah jurusan kuliah yang dimiliki mahasiswa pada dua variabel demografi, yaitu urutan pilihan kuliah dan pihak yang menentukan jurusan kuliah. Pada variabel urutan pilihan jurusan kuliah terdapat perbedaan yang signifikan antara subjek yang memilih jurusan yang sedang dijalani sebagai pilihan pertama dengan pilihan ketiga. Subjek yang memilih jurusan kuliah yang saat ini dijalani sebagai pilihan ketiga, memiliki intensi untuk pindah jurusan yang lebih tinggi dibandingkan dengan subjek yang memilih jurusan kuliah saat ini sebagai pilihan pertama. Hal tersebut terjadi karena umumnya pilihan jurusan ketiga bukanlah jurusan yang benar-benar dinginkan oleh subjek. Namun, pilihan tersebut biasanya hanyalah pilihan terakhir yang dibuat oleh individu ketika tidak memungkinkan untuk memilih jurusan yang diinginkannya. Oleh karena itu, mahasiswa yang menjalani kuliah pada pilihan jurusan kuliah yang ketiga memiliki kemungkinan yang lebih besar untuk mengalami salah jurusan kuliah, sehingga mereka juga akan cenderung memiliki intensi yang tinggi untuk pindah jurusan kuliah.

Selain itu, pada variabel pihak yang memilihkan jurusan kuliah, terdapat perbedaaan intensi pindah jurusan kuliah yang signifikan antara mahasiswa yang memilih jurusan kuliah karena keinginan sendiri dan mahasiswa yang berkuliah di jurusan yang dipilihkan oleh orang tua. Mahasiswa yang memilih jurusan kuliah karena keinginan orang tua memiliki intensi pindah jurusan kuliah yang lebih besar dari pada mahasiwa yang memilih sendiri jurusan kuliah yang saat ini ia jalani. Hal ini sejalan dengan pernyataan dari Greenhaus dan Callanan (2006), yang menyatakan bahwa intensi seseorang untuk melakukan perubahan karier salah satunya dipengaruhi oleh pilihan karier individu itu sendiri. Mahasiswa yang menentukan sendiri jurusan kuliahnya, akan memilih jurusan kuliah yang sesuai dengan keinginannya, sehingga lebih sedikit kemungkinannya mereka akan mengalami kebimbangan karier akibat salah jurusan. Namun, pada mahasiswa yang jurusan kuliahnya dipilihkan oleh orang tua, terkadang jurusan tersebut tidak sesuai dengan keinginan dari mahasiswa tersebut. Oleh karena itu, mereka akan cenderung merasa salah jurusan ketika sudah menjalani kuliah dan memiliki keinginan yang lebih besar untuk melakukan pindah jurusan kuliah. 
Hasil lain dari penelitian ini juga menunjukkan bahwa tidak terdapat perbedaan yang signifikan antara intensi pindah jurusan kuliah berdasarkan tahun kuliah mahasiswa tersebut. Hal ini tidak sejalan dengan hasil penelitian Ramos (2013), yang menunjukkan bahwa mahasiswa di tahun pertama lebih banyak yang menginginkan untuk pindah jurusan kuliah daripada mahasiswa di tahun terakhir. Perbedaan hasil penelitian ini dapat terjadi karena sebagai negara dengan budaya kolektif, orang tua berperan besar dalam pengambilan keputusan terkait karier pada mahasiswa (Mau, 2000). Oleh karena itu, ketika mahasiswa yang berada di tahun pertama, ataupun di tahun-tahun berikutnya mengalami kebimbangan karier, dan tidak mendapatkan ijin dari orang tua untuk pindah jurusan kuliah, maka intensi mahasiswa untuk pindah jurusan kuliah akan berkurang. Sebaliknya, ketika orang tua menyetujui untuk melakukan pindah jurusan kuliah, maka intensi mahasiswa untuk melakukan pindah jurusan akan meningkat, sekalipun mereka sudah berkuliah di tahun terakhir.

Selain itu, hasil penelitian ini juga menunjukkan tidak ada perbedaan intensi pindah jurusan kuliah yang signifikan berdasarkan variabel IPK, dan persepsi mahasiswa terhadap kemampuan orang tua. Hal ini dapat terjadi karena ketika mahasiswa yang mengalami kebimbangan karier, mereka akan merasa tidak puas dengan pilihan jurusan yang sedang dijalaninya. Ketidakpuasan yang dialami mahasiswa tersebut, membuat mereka menginginkan untuk pindah ke jurusan kuliah yang sesuai dengan keinginannya. Walaupun mahasiswa tersebut memiliki pencapaian akademis yang baik, namun karena jurusan yang dijalani tidak sesuai dengan keinginan, mereka tetap menginginkan untuk pindah jurusan kuliah. Selain itu, ketidakpuasan yang dialami oleh mahasiswa, juga membuat mahasiswa yang mempersepsikan orang tuanya tidak mampu untuk mem- biayai, tetap memiliki keinginan untuk pindah jurusan kuliah.

Penelitian ini memiliki kelebihan dan kekurangan yang dapat dijadikan sebagai bahan pertimbangan untuk pengembangan penelitian berikutnya. Kelebihan dari penelitian ini adalah dapat menggambarkan besaran peran kebimbangan karier dalam memengaruhi intensi pindah jurusan kuliah seorang mahasiswa. Penelitian ini juga memberikan gambaran mengenai keterkaitan antara urutan pilihan jurusan dan pihak yang menentukan pilihan jurusan kuliah terhadap intensi pindah jurusan kuliah yang dimiliki oleh mahasiwa. Selain itu, penelitian ini juga memberikan sumbangan teoretis baru berupa alat ukur intensi pindah jurusan kuliah yang dikembangkan dari theory of planned behavior milik Ajzen (1991).

Sementara itu, penelitian ini juga masih memiliki beberapa kekurangan, seperti pengukuran intensi pindah jurusan kuliah dalam penelitian ini yang hanya dilakukan secara indirect, dimana itemitem dalam kuesioner dibuat hanya berdasarkan studi elisitasi. Pada panduan pembuatan alat ukur intensi yang disusun oleh Francis dkk. (2004), untuk melihat peranan prediktor dari intensi terhadap intensi individu untuk melakukan suatu perilaku, maka perlu dilakukan pengukuran secara direct dan indirect. Kedua pengukuran tersebut dibutuhkan untuk dapat melihat peran dari masing-masing prediktor terhadap intensi secara lebih mendalam.

\section{Simpulan dan Saran}

\section{Simpulan}

Hasil penelitian ini menunjukkan bahwa kebimbangan karier yang dialami berperan terhadap intensi mahasiswa untuk melakukan pindah jurusan kuliah, dengan peran sebesar $4.7 \%$. Hasil lain dari penelitian ini menunjukkan bahwa mahasiswa yang memilih jurusan kuliah sebagai pilihan ketiga dan mahasiswa dengan jurusan kuliah yang dipilihkan oleh orang- 
tua memiliki intensi pindah kuliah yang lebih tinggi.

\section{Saran}

Beberapa saran yang dapat diberikan berdasarkan hasil penelitian ini, berupa saran teoretis maupun praktis. Penelitian selanjutnya, disarankan untuk melakukan pengembangan alat ukur intensi pindah jurusan kuliah yang disusun secara direct measurement. Dimana alat ukur dibuat dengan menambahkan item-item yang disusun berdasarkan konstruk teoretis dari intensi pindah jurusan kuliah, serta disusun berdasarkan tujuan dari penelitian. Sehingga alat ukur intensi pindah jurusan yang dibuat dapat lebih menggambarkan peranan dari masing-masing prediktor intensi secara lebih jelas.

Selanjutnya pada tataran praktis, bagi orang tua agar dapat memberikan kebebasan kepada anak untuk memilih jurusan kuliah yang diinginkannya dan memberikan support terhadap pilihan tersebut. Selanjutnya untuk mencegah calon mahasiswa (siswa SMA) memiliki intensi pindah jurusan kuliah yang tinggi, pihak SMA (guru, bagian bimbingan konseling, dan lain-lain) dapat memberikan intervensi kepada calon mahasiswa dengan memberikan pelatihan mengenai pentingnya menentukan pilihan karier agar tidak salah dalam memilih jurusan. Terakhir, bagi pihak universitas dapat memberikan bantuan kepada mahasiswa yang mengalami kebimbangan karier dengan memberikan konseling kepada mahasiswa agar dapat mengatasi kebimbangan karier yang dialaminya.

\section{Daftar Pustaka}

Ajzen, I. (1991). The theory of planned behavior. Organizational Behavior and Human Decision Processes, 50. 179-211.

(2011). The theory of planned behavior: Reactions and reflections. Psychol Health, 26(9), 1113-1127. doi:

10.1080/08870446.2011.613995. (2012). The theory of planned behavior. Dalam P.A.M.V. Lange, A.W. Kruglanski, \& E.T. Higgins (Eds.), Handbook of theories of social psychology (Vol. 1, pp. 438459). London: SAGE Publications Ltd.

Anschuetz, N. (2015). Breaking the 4-year myth: Why students are taking longer to graduate. Diakses pada tanggal 2 November 2016, dari http://college.usatoday.com

Coco, R. F. (2000). Construct validity of the career decision scale with hispanic high school students (Thesis). Seton Hall University, United States.

Crown Financial Ministries. (2007). Common career mistakes and how to avoid them. Diakses pada tanggal 5 Mei 2017, dari http://www.focusonthefamily.com/li fechallenges/lifetransitions/making-a-careerchange/making-common-careermistakes-and-how-to-avoid-them

Daniels, L. M., Stewart, T. L., Stupnisky, R. H., Perry, R. P., \& LoVerso, T. (2011). Relieving career anxiety and indecision: The role of undergraduate students' perceived control and faculty affiliations. Social Psychology of Education, 14(3), 409-426. doi: 10.1007/s11218-010-9151-x.

Foraker, M. J. (2012). Does changing majors really affect the time to graduate? The impact of changing majors on student retention, graduation, and time to graduate. Office of Institutional Research. Trans., Kentucky: Western Kentucky University.

Francis, J. J., Eccles, M. P., Johnston, M., Walker, A., Grimshaw, J., Foy, R., \& Bonetti, D. (2004). Constructing questionnaires based on the theory 
of planned behaviour: A manual for health services researchers. UK: Centre for Health Services Research, University of Newcastle upon Tyne.

Gordon, V., \& Steele, G. (2003). Undecided first-year students: A 25year longitudinal study. Journal of the First-Year Experience \& Students in Transition, 15, 19-38.

Greenhaus, J. H., \& Callanan, G. A. (2006). Encyclopedia of career development (Vol. 1). Thousand Oaks, California: SAGE Publications.

Guay, F. (2006). Distinguishing developmental from chronic career indecision: Self-efficacy, autonomy, and social support. Journal of Career Assessment, 14(2), 235-251. doi: $10.1177 / 1069072705283975$.

Intani, F. S., \& Surjaningrum, E. R. (2010). Coping strategy pada mahasiswa salah jurusan. INSAN, 12, 119-126.

Irianto, A. (2004). Statistik: Konsep dasar, aplikasi, dan pengembangannya. Jakarta: Kencana.

Johnson, D. (2005). Predicting college students who change majors reasons and motivation of major changes (Disertasi). University of Idaho, United States.

Jones, L., \& Jones, J. (2012). Personalitycollege major match and student success: A guide for professionals helping youth and adults who are in college or are college-bound. Diakses pada 5 Mei 2017 dari http://www.careerkeyca.org/pdf/Ca nadian_Professionals_Guide_Perso nality_Major_Match.pdf

Kim, H., \& Kim, O. (2017). Self-regulated learning and social factors affecting major satisfaction of Korean college students. International Information Institute (Tokyo). Information, 20(1A), 99.

Mahoney, R., Katona, C., McParland, M., Noble, L., \& Livingston, G. (2004).
Shortage specialties: Changes in career intentions from medical student to newly qualified doctor. Med Teach, 26(7), 650-654. doi: 10.1080/01421590400019591.

Mau, W. C. (2000). Cultural differences in career decision-making styles and self-efficacy. Journal of Vocational Behavior, 57(3), 365-378. doi: 10.1006/jvbe.1999.1745.

Nugroho, J. (2016). Salah ambil Prodi, 100 siswa yang lolos di UGM mundur. Diakses pada 13 April 2017 dari http://www.harianjogja.com/baca/2 016/01/25/snmptn-2016-salahambil-prodi-100-siswa-yang-lolosdi-ugm-mundur-684187

Oktaviani, M. A., \& Notobroto, H. B. (2014). Perbandingan tingkat konsistensi normalitas distribusi metode kolmogorov-smirnov, lilliefors, shapiro-wilk, dan skewness-kurtosis. Jurnal Biometrika dan Kependudukan, 3(2), 127-135.

Pečjak, S., \& Košir, K. (2007). Personality, motivational factors and difficulties in career decision-making in secondary school students. Psihologijske teme, 16(1), 141-158.

Peterson, K. F. (2006). Changing their majors: How do students choose their majors and why do so many change? (Thesis). University of Minnesota, United States.

Ramos, Y. (2013). College students tend to change majors when they find the one they really love. Diakses pada tanggal 11 November 2016, dari http://borderzine.com

Sklar, J. (2014). The impact of change of major on time to bachelor's degree completion with special emphasis on STEM disciplines: A multilevel discrete-time hazard modeling approach final report. Statistics Department, Trans., California: California Polytechnic State University. 
Taylor, S. (2013). Factors affecting change in major and college persistence for traditional and nontraditional community college students (Disertasi). Alliant International University, United States.

Welcome, S. L. (2014). Expectation versus reality: The impact of academic advising on nontraditional community college students seeking a career change (Disertasi). Capella University, United States. 
Psympathic, Jurnal Ilmiah Psikologi Juni 2018, Vol. 5, No. 1, Hal: 83-94 